\title{
地磁気変化による誘導電位変化の除去の試み
}

\author{
高山 寛美・森 俊雄
}

\section{A Trial of Elimination of Geoelectric Field Variations Induced by Geomagnetic Variations}

\author{
by \\ Hiromi Takayama and Toshio Mori \\ Meteorological Research Institute, Tsukuba, Ibaraki 305, Japan
}

(Received Aug. 9, 1986; Revised Nov. 28, 1986)

\begin{abstract}
A model built in the time domain between geomagnetic variations and geoelectric field variations is applied to observation values. The parameters of the model are obtained by minimizing AIC (Akaike Information Criterion). The model with parameters obtained estimates the geoelectric field variations induced by geomagnetic variations and the residuals are calculated by subtracting the estimated values of the induced geoelectric field variations from the observation values.

The result indicates that this method is available for variations with periods between a few hours and a few days. The spectral density of the residual geoelectric fields has peaks with periods of $\mathrm{O}_{1}$ and $\mathrm{M}_{2}$ constituents. On the contrary, that of the observation fields has peaks with periods of $S_{1}, S_{2}, S_{3}$ etc.
\end{abstract}

\section{1.はじめに}

観測される地電位差の原因としては，地磁気変 化による誘導電位変化, 電気鉄道や工場などの電 気施設からの漏電, 地中での化学作用による電位 差, 電荷をもつ水などの移動, 結晶の圧電効果, 電光放射等の大気現象など種々考兄られる。地電 位差変化のうち長周期変化は電極の接触電位など の影響がいちじるしいが，周期 1 日以下の短周期 変化については，地磁気変化との相関があり，大 きな部分を占めている(力武，1972）。したがって 観測された地電位差データから地殼活動に伴う自 然電位変化を検出するためには，この地磁気変化 による誘導電位変化を除く必要がある。このこと は吉松 (1937a) 以来, 柿岡地磁気観測所構内に招 いて, 平行する長短 2 本の基線で地電位差を測定 し，地磁気変化による誘導電位変化が基線長に依
存することから，それらの重み付きの差（差電位 差）をとることによって試みられて扣り，地震の 前に変化した例も報告されている（吉松，1937b， 1938, 1943,1984；柳原・横内，1967）。

現在日本電信電話株式会社 $(\mathrm{N} \mathrm{T} \mathrm{T})$ の好意に より電話局のアースとそれらの間の通信ケーブル 施設を利用して, 数 $10 \mathrm{~km}$ の長基線の地電位差観測 を行っている（森，1985；Mori,1987）。そのらち 水戸で観測している電話局の位置をFig.1に示 す。この観測による地電位差データは人工的擾乱 によるノイズはかなり小さく，地磁気変化による 誘導電位変化の部分が大きい。そこで，この地電 位差観測データから地磁気変化による誘導電位変 化を除去し，地殼活動等に伴ら自然電位変化の検 出を試みた。な和地磁気变化は柿岡地磁気観測所 に括ける地磁気データを使用した。 


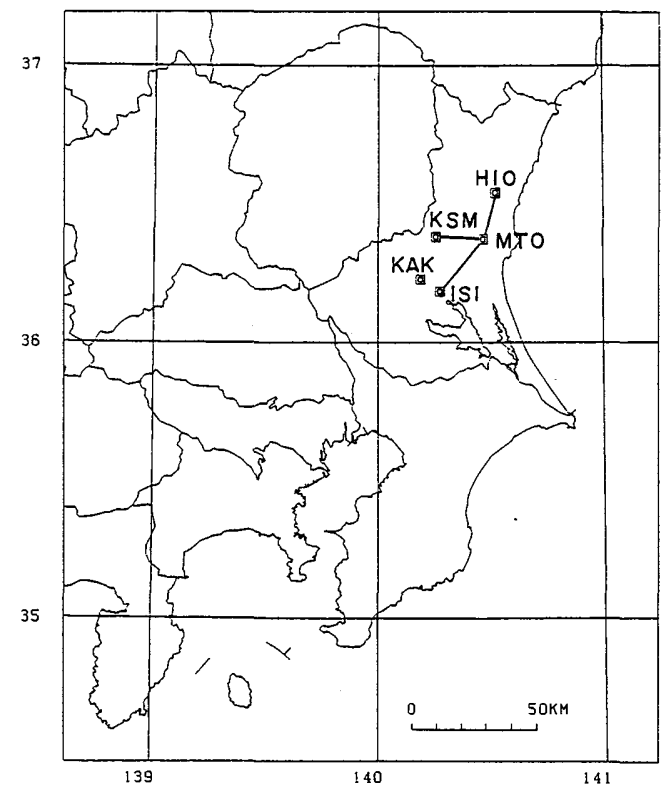

Fig.1 Map showing observation sites, which are the repeater stations of the Nippon Telegraph and Telephone Corporation (NTT). MTO:Mito, ISI:Ishioka, KSM:Kasama, HIO:Hitachiohta, KAK:Kakioka Magnetic Observatory.

\section{2. 方 法}

地磁気変化による地電位変化を推定する方法と して, 各種の電気探査によって地下の電磁気的構 造を求めて, それによって地磁気变化に対する地 電位差変化の応答特性を得て行らことが考光られ る。しかし，3次元的な構造を仮定すると大規模 な計算を必要とする。そこで地電位差変化を地磁 気変化の回帰式で表わすモデルを仮定し, 観測值 に適用して得られたパラメータをもつモデルに よって地磁気変化による誘導電位变化を推定する ことにする。

地磁気変化による誘導電位変化は, 電磁気的に 均質等方性の半無限媒質の場合, 周期的な変化に 対しては次のよらに考光られる。磁場変化Hが水 平面内のある方向にのみ存在し，その周期を $\mathrm{T}$,

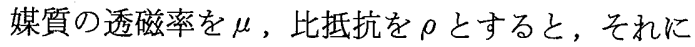
よって誘導される電場 $\mathrm{E}$ は; 水平面内で $\mathrm{H}$ 亿直交 する方向に生じ，EとHの間には，

$$
\frac{\mathrm{E}}{\mathrm{H}} \propto \sqrt{\frac{\mu \rho}{\mathrm{T}}} \mathrm{e}^{(\pi / 4) i}
$$

の関係がある。すなわち，電場は磁場に対して， 位相が $\pi / 4$ だけ進み，その振幅比は $1 / \sqrt{T} に$
比例する。

一般に磁場変化と電場変化は線形関係にあるの で, 時間領域において, 任意の方向の地電位差 $\mathrm{C}$

( $t$ ） は, 地磁気変化の南北成分 $X(t)$, 東西成 分Y $(t)$ と次の関係が期待される。ただし，す べてその平均值を差し引いたものとする。

$$
\begin{aligned}
\mathrm{C}(\mathrm{t})= & \sum_{m=-L}^{K}\{\mathrm{a}(\mathrm{m}) \mathrm{X}(\mathrm{t}-\mathrm{m}) \\
& +\mathrm{b}(\mathrm{m}) \mathrm{Y}(\mathrm{t}-\mathrm{m})\}+\varepsilon(\mathrm{t})
\end{aligned}
$$

ここで $\mathrm{a}(\mathrm{m})$ 和よび $\mathrm{b}(\mathrm{m})$ はそれれ゙゙れ地磁気 変化の南北成分 $X(t)$ と東西成分 $Y(t)$ に対 する応答特性を表わす係数, $\varepsilon(t)$ は地電位差 の観測値のらち地磁気変化による誘導電位変化以 外のものであり, 観測上のノイズも含んでいる。 コンボリューションの中で応答の係数に負の部分 があるのは，位相の進みを考慮したものである。

このモデルを任意の区間の地磁気预よび地電位 差の観測値に適用し，AＩＣ（赤池の情報量基 準）を最小にする $\mathrm{K}, \mathrm{L}, \mathrm{a}(\mathrm{m}), \mathrm{b}(\mathrm{m}),(\mathrm{m}$ $=-\mathrm{L}, \cdots \cdots, \mathrm{K})$ を求める。A I C は次式で 定義される量である（赤池, 1976)。

A I C $=-2 \times$ (モデルの最大対数尤度)

$+2 \times$ (モデルの自由パラメータ数）

回帰モデルについては次のようになる。

$$
\mathrm{AIC}=n \log 2 \pi+n \log d(p)+n+2 p
$$

ここで $\mathrm{n}$ はデータ数, $\mathrm{p}$ はパラメータ数, $\mathrm{d}$

（p）忙その時の残差分散である。この場合 $\mathrm{p}=$ $2 *(\mathrm{~K}+\mathrm{L}+1)+1, \mathrm{~d}(\mathrm{p})$ は $\varepsilon(\mathrm{t})$ の 平均 2 乗誤差である。な招パラメータ数は $2 \sqrt{n}$ 程度以下でなければならない。AＩＣはその值の 差に意味があり， 1〜2程度以上なら A I C の值 の差は有意であると考兄られる（坂元ほか，1983）。

この方法で決めた係数と地磁気変化の観測值と のコンボリューションを地磁気変化による誘導電 位変化の推定值之考兄, その地電位差観測值から の差を計算する。

\section{3. 計算結果}

柿岡地磁気観測所における地磁気变化と笠間一 水戸間 $\left(19.0 \mathrm{~km}, \mathrm{~N} 87^{\circ} \mathrm{W}\right)$ の地電位差の観測値 の例をFig.2に示す。サンプリング間隔は60分で, 期間は1985年 3 月 8 日から 8 月16日までである。 データは 1 秒值を 3600 個平均したものである。

区間A（Aのついたせで示した区間）にモ デルを適用した。KとLをそれぞれ横軸と縦軸と 
$8538 \mathrm{D} O \mathrm{OH}$ OM $-817 \mathrm{D}$ OH OM (JST), DT = 60 MIN, NDATA $=3889$

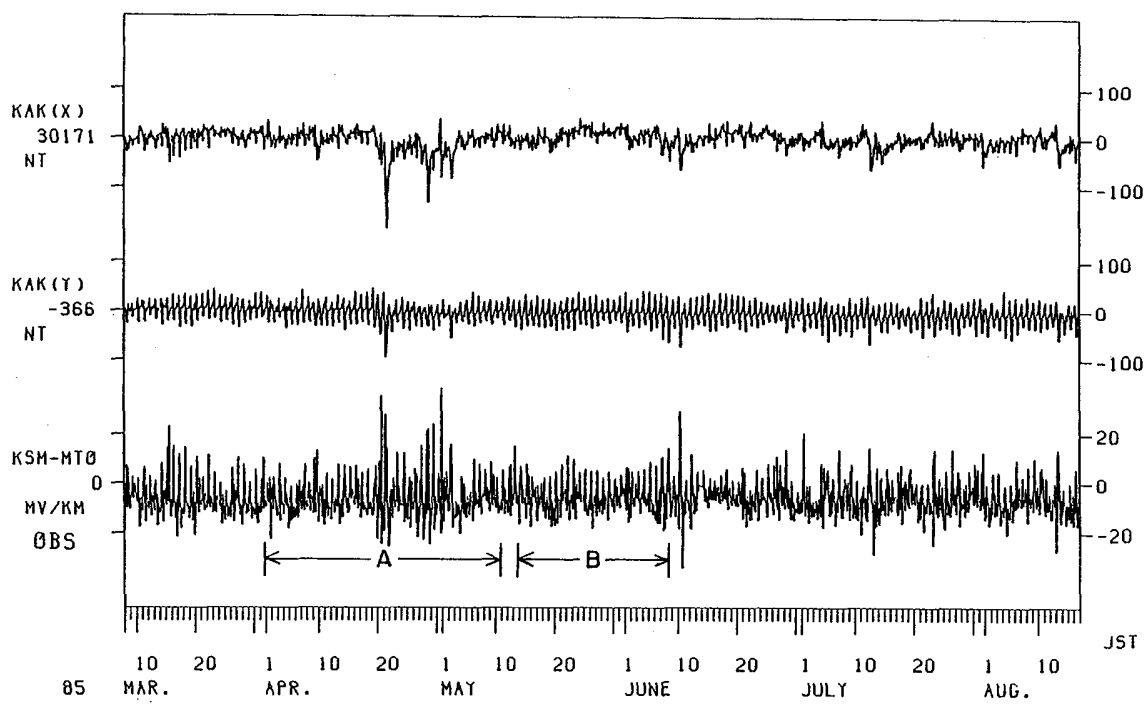

Fig.2 Example of observation values. The top one is NS component $(X)$ of the geomagnetic variations at the Kakioka Magnetic Observatory. The middle one is EW component(Y). The bottom one is the geoelectric field variations between Kasama and Mito. A and B indicate intervals to which the model is applied.

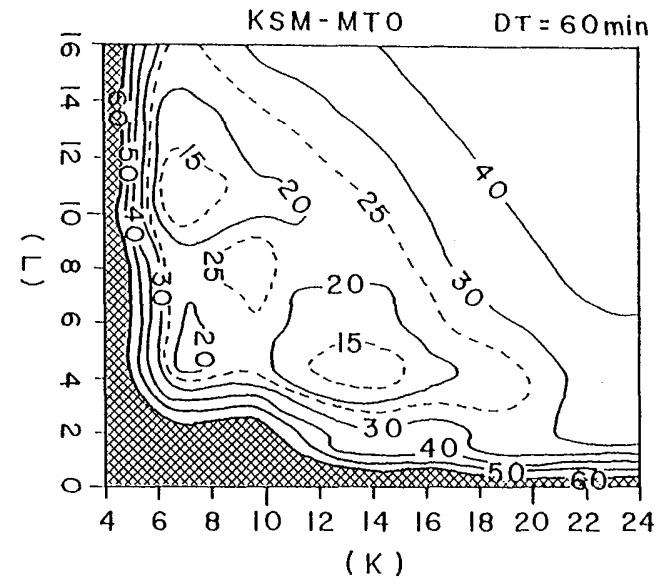

Fig.3 Contour map of AIC. Abscissa and ordinate are $\mathrm{K}$ (backward) and $\mathrm{L}$ (forward), respectively. 4600 should be added to values of AIC. Contours are omitted in the shaded part.

してAＩＣの等値線図をFig.3に示す。ただし図 の中の数值は4600をひいたものであり，また網を かけた部分は外側に向かって急激にA I C の值が 大きくなっている。データ数が960個であり，パ ラメータ数 $\mathrm{p}$ の上限は60程度, $\mathrm{K}+\mathrm{L}$ の上限は30 ぐらいである。この範井での極小值としては，
$(\mathrm{K}, \mathrm{L})=(7,5)$ で4617.42,(7,11) で 4611.61，(14,4) で4613.14がある。これらのら ち, A I Cの值の差が $1 \sim 2$ 程度以上のとき有意 であること, 応答特性の係数で負の部分の項数L があまり大きくない方が合理的であることを考慮 し， $\mathrm{K}=14 ， \mathrm{~L}=4$ の場合を選択した。その時の 係数をTable 1とFig.4の上段に示す。比較的大き な值は土 1 の範囲に限られて初り，地磁気変化の 南北成分Xに対する係数之東西成分Yに対する係 数の大ささ怕同程度である。これらの係数をフー リ工変換して得られる周期特性をFig.4の中・下 段に示す。その振幅特性（中段）はほぼ $1 / \sqrt{\mathrm{T}}$ に比例している。笠間一水戸間の基線は汪注東西 であるにもかかわらず，地磁気変化の南北成分 X だけではなく東西成分Yによる誘導電位変化も大 きいことを示している。

ここで得られた係数を使って地磁気変化による 誘導電位変化を推定し, 観测値から差し引いて残 差を計算した結果をFig.5に示す。上から柿岡地 磁気観測所に扣汗る地磁気変化の南北成分 $\mathrm{X}$, 東 西成分Y, 地電位差の観测值，地磁気変化による 誘導電位変化の推定值, 残差の順である。数時間 から 3 日ぐらいの周期の変化はかなり良く推定さ れていると考学られ，その分散は約 $1 / 8$ になっ 


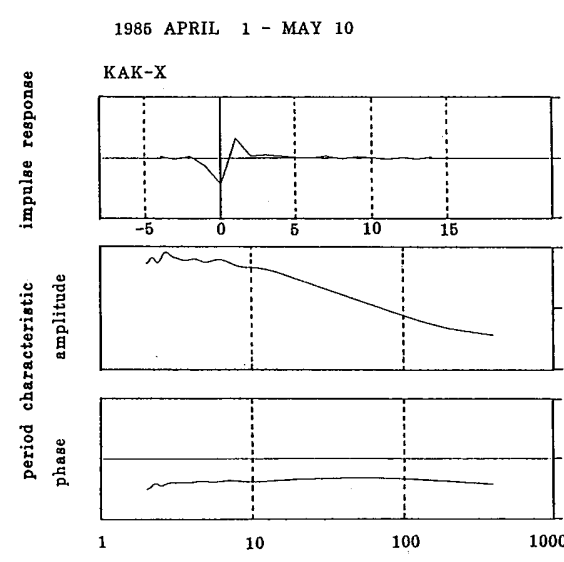

(model A)
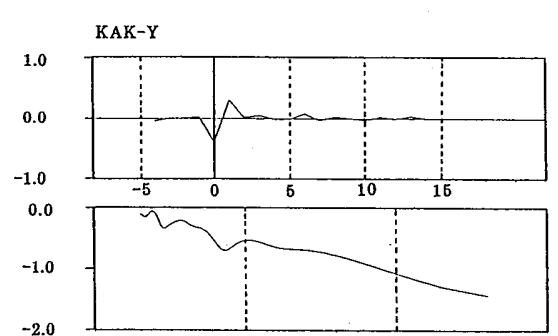

Fig.4 Characteristics of model A with parameters determined due to interval A.

The left half is for $\mathrm{X}$ component and the right half is for $\mathrm{Y}$ component.

From top to bottom, impulse response in $\mathrm{mV} / \mathrm{km} / \mathrm{nT}$, amplitude characteristic in common logarithms in $\mathrm{mV} / \mathrm{km} / \mathrm{nT}$, and phase characteristic in radian.

Table 1 Parameters obtained by applying models to intervals $\mathrm{A}(\mathrm{left})$ and $\mathrm{B}$ (right).

\begin{tabular}{|r|r|r|}
\hline \multicolumn{2}{|r|}{ Mode 1} & $A$ \\
\hline $\mathrm{X}$ & $\mathrm{m}$ & $\mathrm{Y}$ \\
\hline 0.031 & -4 & -0.048 \\
-0.023 & -3 & -0.003 \\
0.030 & -2 & 0.003 \\
-0.136 & -1 & 0.028 \\
-0.434 & 0 & -0.401 \\
0.339 & 1 & 0.315 \\
0.035 & 2 & 0.017 \\
0.050 & 3 & 0.049 \\
0.030 & 4 & -0.014 \\
0.013 & 5 & -0.008 \\
0.002 & 6 & 0.081 \\
0.033 & 7 & -0.038 \\
-0.017 & 8 & 0.028 \\
0.024 & 9 & 0.000 \\
0.008 & 10 & -0.032 \\
-0.026 & 11 & 0.026 \\
0.010 & 12 & -0.011 \\
-0.024 & 13 & 0.033 \\
0.024 & 14 & 0.004 \\
\hline
\end{tabular}

\begin{tabular}{|r|r|r|}
\hline \multicolumn{3}{|c|}{ Model $\mathrm{B}$} \\
\hline $\mathrm{X}$ & $\mathrm{m}$ & \multicolumn{1}{|c|}{$\mathrm{Y}$} \\
\hline-0.079 & -1 & 0.005 \\
-0.474 & 0 & -0.255 \\
0.398 & 1 & 0.202 \\
0.002 & 2 & 0.070 \\
0.045 & 3 & 0.043 \\
0.010 & 4 & 0.037 \\
0.049 & 5 & 0.001 \\
-0.004 & 6 & 0.018 \\
0.022 & 7 & -0.008 \\
-0.016 & 8 & 0.088 \\
0.013 & 9 & -0.043 \\
0.036 & 10 & 0.001 \\
-0.003 & 11 & 0.030 \\
0.008 & 12 & -0.019 \\
-0.021 & 13 & 0.042 \\
0.002 & 14 & 0.024 \\
-0.041 & 15 & 0.037 \\
\hline
\end{tabular}

Interval A (model A)

( MODEL) BS 4 ID $1 \mathrm{H}$ OM. $N=950 . K=14, \mathrm{~L}=4$, MFPEC $=38$,

1 〈DATA BS 4 ID $1 \mathrm{H}$ OM. $N=960 . \quad$ OT $=80 \mathrm{HIN}$

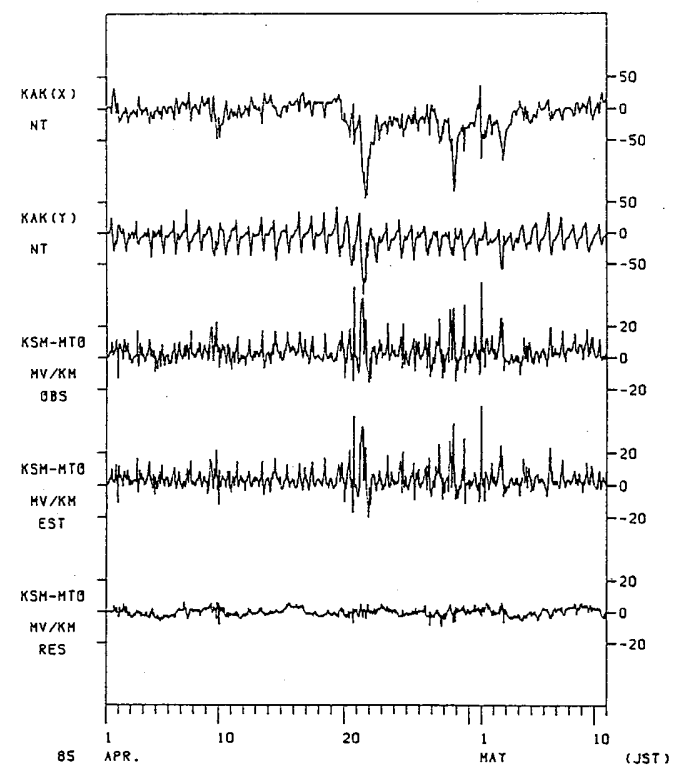

Fig.5 Result obtained by applying model A to interval A. The upper three curves are the observation values of the geomagnetic and geoelectric field variations. The fourth represents the estimated values of the induced geoelectric field variations, the bottom one the residuals left by subtracting the estimated values from observation values. 


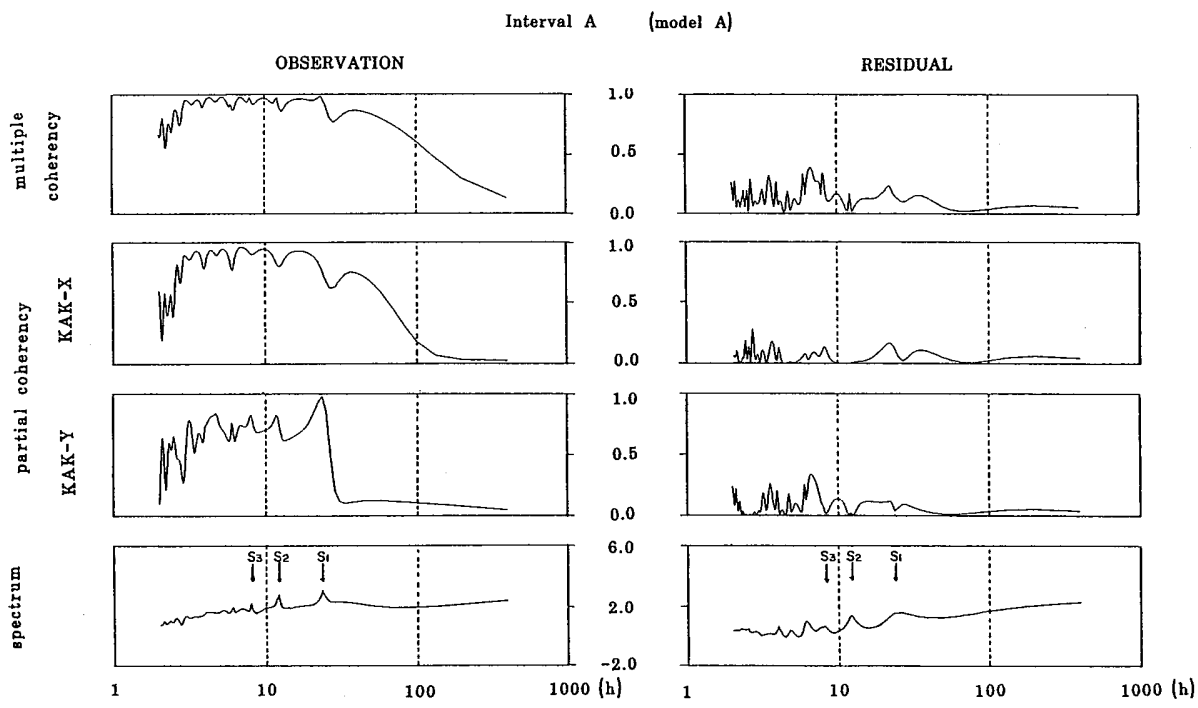

Fig.6 Characteristics in the frequency domain of the time series in Fig.5. The left half is for observation values and the right half for the residuals. The upper three curves are multiple and partial coherencies and the bottom one spectral density in common logarithms in $(\mathrm{mV} / \mathrm{km})^{2} *$ hour.

ている。地磁気擾乱による大さな地電位差変化は かなり取り除けている。しかし残差に見られる 3 時間程度以下の周期の変化が, 観測值のノイズか 1 時間というサンプリング間隔によるものかはわ からない。一方 1 日以上の周期，特に $5 \sim 7$ 日周 期の変動が目立つが，これは観測值にみられる変 動がそのまま残ったものである。

この時系列の周波数領域での性質をFig.6に示 す。左側が地電位差観測值について，右側はその 残差についてのものである。観測值において，3 時間から 3 日ぐらいの周期の範囲で地磁気変化と の関連の強いことを示している。それに対し，残 差においては全般にコヒーレンシーが低く，地磁 気変化に関連した部分はかなり取り除けていると 考えられる。スペクトルではともに $\mathrm{S}_{1}$ （周期24. $0 \mathrm{~h}), \mathrm{S}_{2}(12.0 \mathrm{~h}), \mathrm{S}_{3}(8.0 \mathrm{~h})$ 等の太 陽に関係する分潮の周期でピークが見られるが， 観測值では非常に鋭く，残差ではややなだらかに なっている。

Fig.7は，区間Aについて求めたパラメータを 持つモデルを他の区間 B (Fig.2でBのついた —で示した区間) に適用した例である。区間 $\mathrm{B}$ は 5 月13日から 6 月 8 日までの約 26 日間でデータ 数は623個である。区間Aでの例と同様に残差に 5〜 7 日の長周期変動がみられる。この時系列の
周波数領域での性質をFig.8に示す。残差のコ ヒーレンシーは, $\mathrm{S}_{1}, \mathrm{~S}_{2}, \mathrm{~S}_{3}$ 等の分潮の周期付

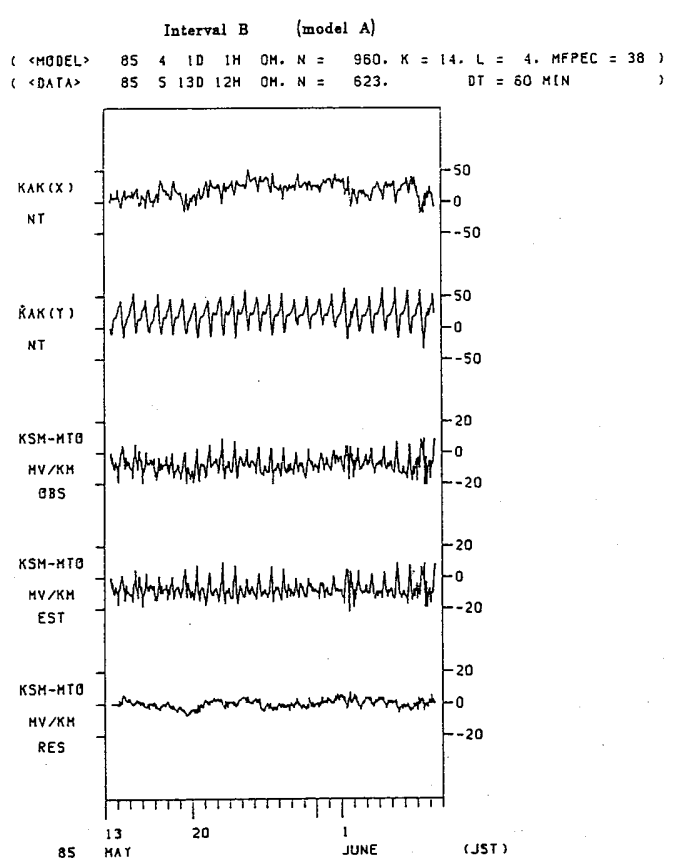

Fig.7 Result obtained by applying model A to interval $\mathrm{B}$. The legends are the same as in Fig.5. 


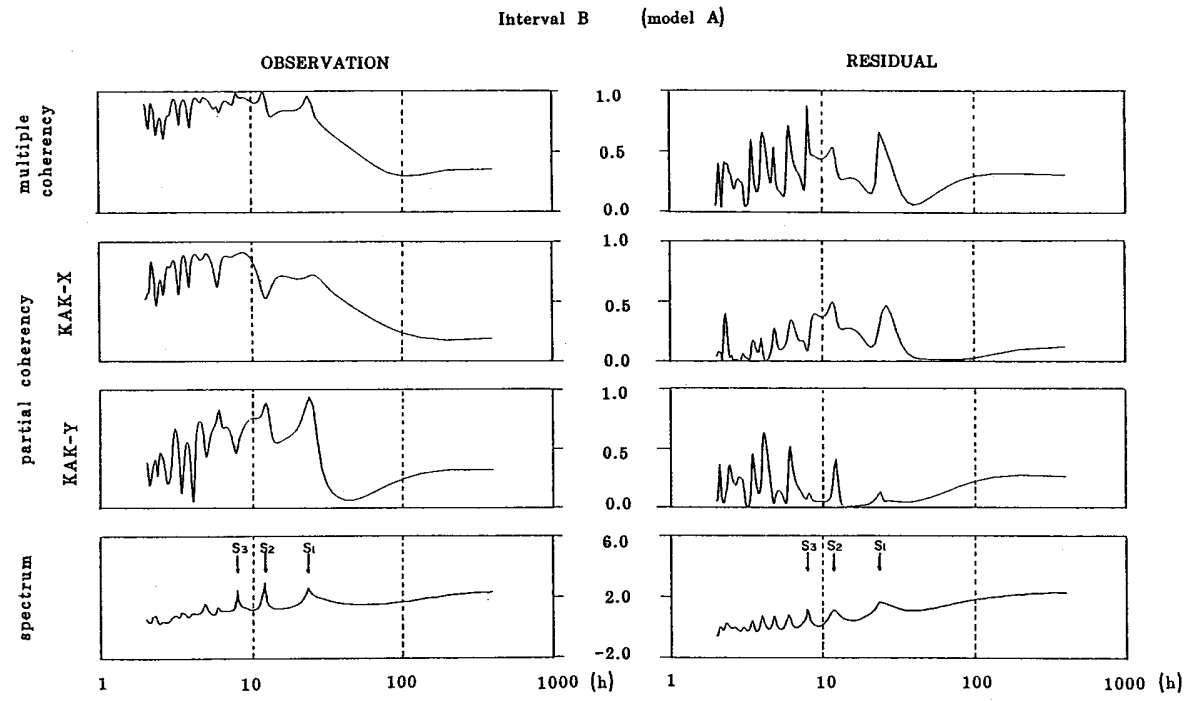

Fig.8 Characteristics in the frequency domain of the time series in Fig.7. The legends are the same as in Fig.6.

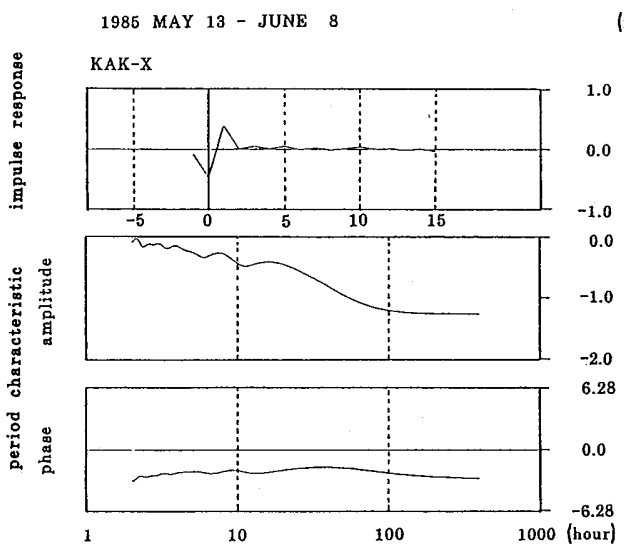

(model B)

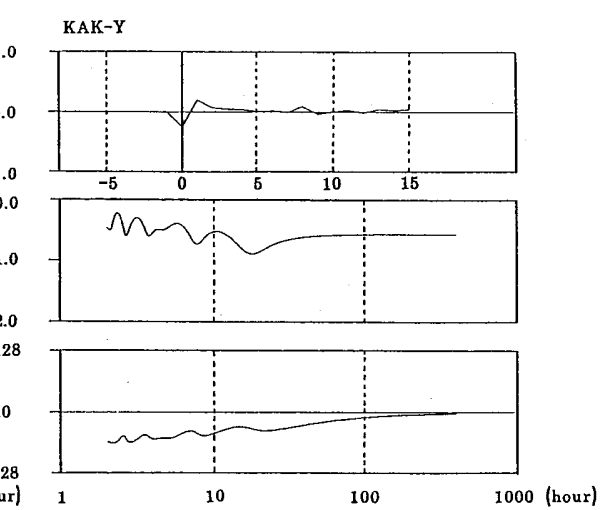

Fig.9 Characteristics of model B with parameters determined due to interval B. The legends are the same as in Fig.4.

近において観測值についてのものより低くなって いるが，Fig.6と比較すると高く，地磁気変化に よって誘導された地電位差変化が，いくらか残っ ていると考兄られる。スペクトルに招いてはピー クの鋭さはなくなっているが, $\mathrm{S}_{1}, \mathrm{~S}_{2}, \mathrm{~S}_{3}$ 等の 周期付近にピークは見られる。

次に区間 Bにモデルを適用乙得られた係数を Table 1 とFig.9の上段に示す。この場合 $K=15$ ， $\mathrm{L}=1$ である。区間 $\mathrm{A}$ につて得られた係数と同 椂な傾向をもつが，Xに対する係数の大きさと $\mathrm{Y}$ に対する係数の大きさが，区間Aについてはほぼ 同程度であったが，区間Bについては前者が後者
に比べてかなり大きい。また周波数領域でみる と，Yに対する振幅特性で長周期の部分が減衰し ていかない。これは区間BのY成分にみられるわ ずかなドリフトによるものである。一方X成分に 対する周期特性は区間 Aについて得られたものと ほぼ一致している。

この区間 $\mathrm{B} て ゙$ 得られたパラメータをもつモデル を使って，同じ区間の地磁気変化による誘導電位 変化を推定し, その観測值からの残差を計算し, それらをFig.10に示す。区間Aから得られたパラ メータをもつモデルを使ったFig.7と良く一致し ている。そのスペクトルと地磁気変化にたいする 


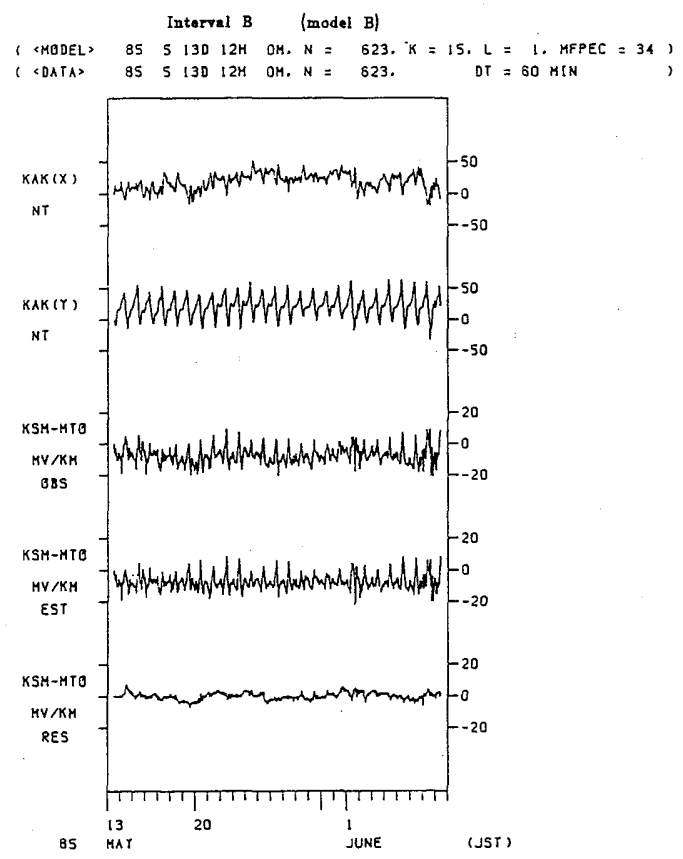

Fig.10 Result obtained by applying model B to interval $B$. The legends are the same as in Fig.5.

コヒーレンシーをFig.11に示す。区間Aから得ら れたパラメータをもつモデルを使った場合の結果

(Fig.8) と比較して, 地磁気変化による誘導電位
変化の推定は当然さらに良くなっている。しか 乙，区間Aでの結果（Fig.6）と比較すると，X成 分についてのパーシャル・コヒーレンシーがやや 高い。

区間Aと区間Bについて得られたパラメータを もつモデルを 3 月 8 日から 8 月16日までの観測值 に適用し，それぞれの残差をFig.12に示す。上段 に地磁気变化のX成分を示し，モデル区間をせ てて示した。区間 Bによる残差で特徵的に見られ ることは, 短周期変化の振幅がモデル区間に比べ てその他の期間に括いて大さいことである。これ はFig.2で見られるように，区間Aが大きな磁気 嵐を含んでいるのに対し，区間B恰んでいない といら違いによると考えられる。1 日より長い周 期の変動は両方ともによく一致している。同図の 下段に水戸地方気象台に扣ける有感地震と日降水 量（水戸地方気象台，1985）を示す。これらと関 連すると思われる地電位差の残差の変化は見られ ない。

同時に観測を行っている他の基線のデータに適 用した結果をFig.13に示す。上から石岡一水戸間 $\left(27.4 \mathrm{~km}, \mathrm{~S} 40^{\circ} \mathrm{W}\right)$ ，笠間一水戸間 $(19.0 \mathrm{~km}, \mathrm{~N}$ $\left.87^{\circ} \mathrm{W}\right)$, 常陸太田一水戸間 $\left(18.8 \mathrm{~km}, \mathrm{~N} 15^{\circ} \mathrm{E}\right)$ の残差, 柿岡地磁気観測所に招汀地磁気のX成 分，Y成分である。モデルのパラメータを得るた めに用いた区間は 4 月 1 日から5月10日まで（区 間A）であり，サンプリング間隔は 1 時間である。

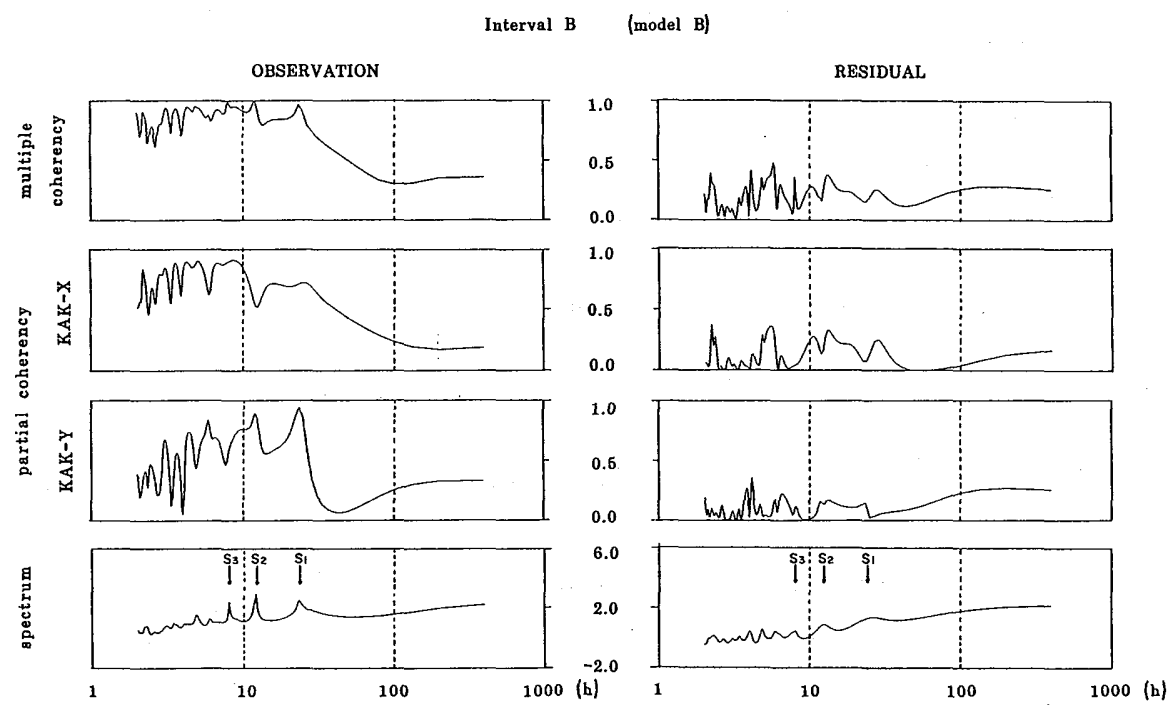

Fig.11 Characteristics in the frequency domain of the time series in Fig.10. The legends are the same as in Fig.6. 


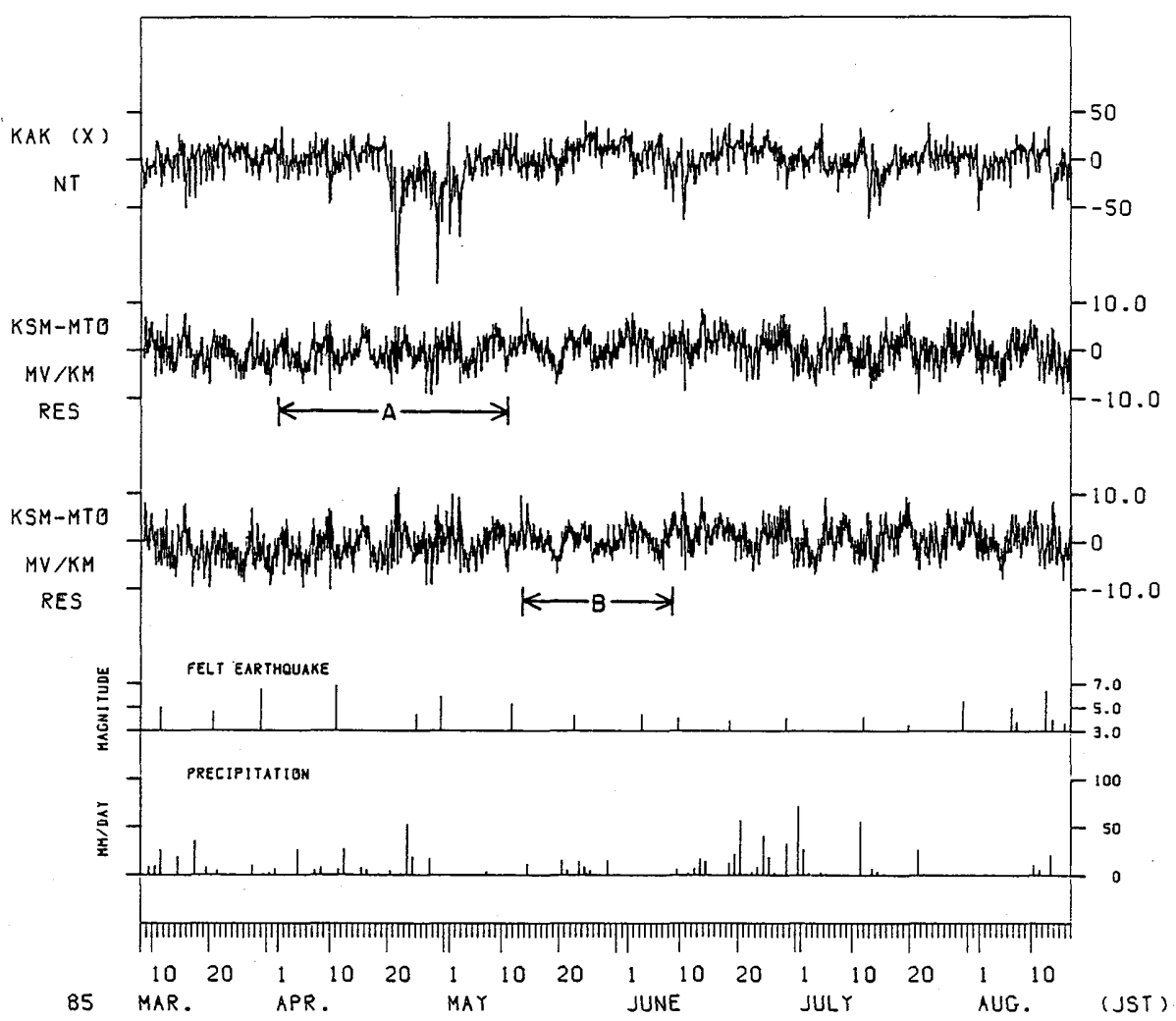

Fig.12 Result obtained by applying models $A$ and $B$ to the interval from March 6 to August 10,1985 . The top curve shows the $\mathrm{X}$ component of geomagnetic variations. The second and the third are residuals, while $\longleftrightarrow$ indicate intervals to which the model is applied. Below are shown the occurence of felt earthquakes and daily precipitation at the Mito Local Meteorological Observatory.

1985 3M 9D OH OM - 8M 16D OH OM (JST) $\quad$ INT $=1$ HOUR

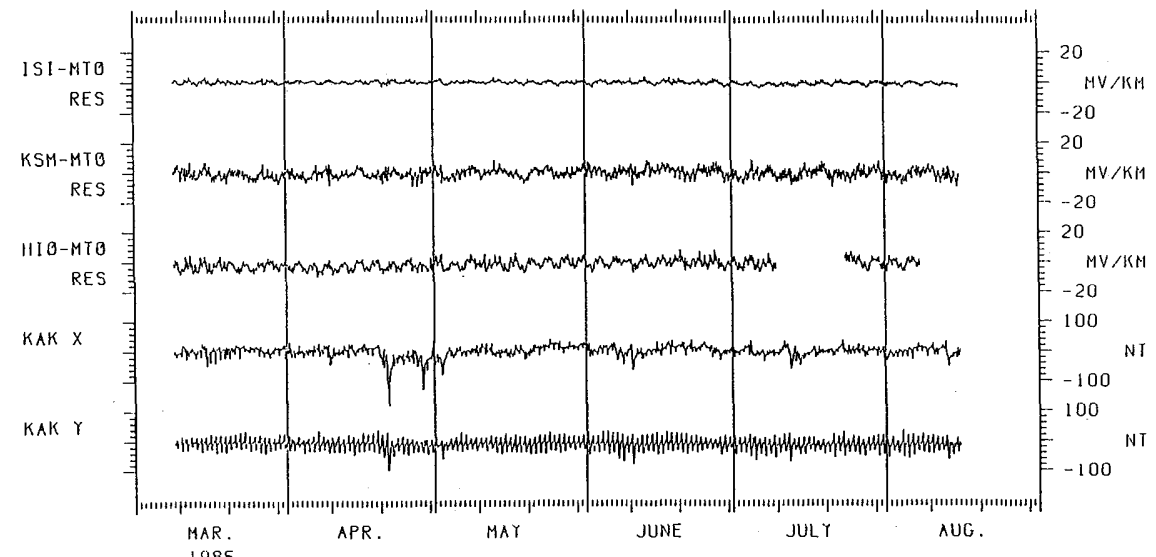

Fig.13 Residual geoelectric fields at the three observation lines. The two lowest curves represent geomagnetic variations. 


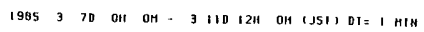
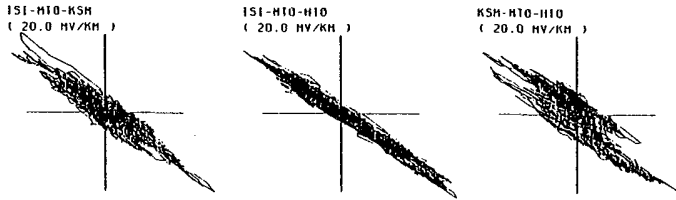

Fig.14 Orbits of the steepest descent direction and the amplitude of the geoelectric field variations.

笠間一水戸間では残差の分散が観測值の分散に対 して約 $1 / 8$ になっているのに，他の 2 つの基線 では約 1／2にしかなっていない。だたし，常陸
太田一水戸間のデータのらち 7 月 10 日から 7 月 22 日までと 8 月 8 日以降は欠測である。常陸太田一 水戸間ではかなり大きく，石岡一水戸間ではわず かであるが， 3〜4 日の周期の変動がみられ，そ の位相も合っているょうである。残差の振幅は笠 間一水戸間と常陸太田一水戸間が同程度であり， 石岡一水戸間ではかなり小さい。

Fig.14は 2つずつの基線によって決まる地電位 差の最大降下の方向とその大きさを示す軌跡であ り，上が北で縦と横のバーは土 $20 \mathrm{~m} \mathrm{~V} / \mathrm{km}$ の大 さを示している。この付近の地域での地電位差変 化の卓越方向は北西一南東方向である。石岡一水 戸間の基線はこれとほぼ直交する向きであるため にその变化は非常に小さい。

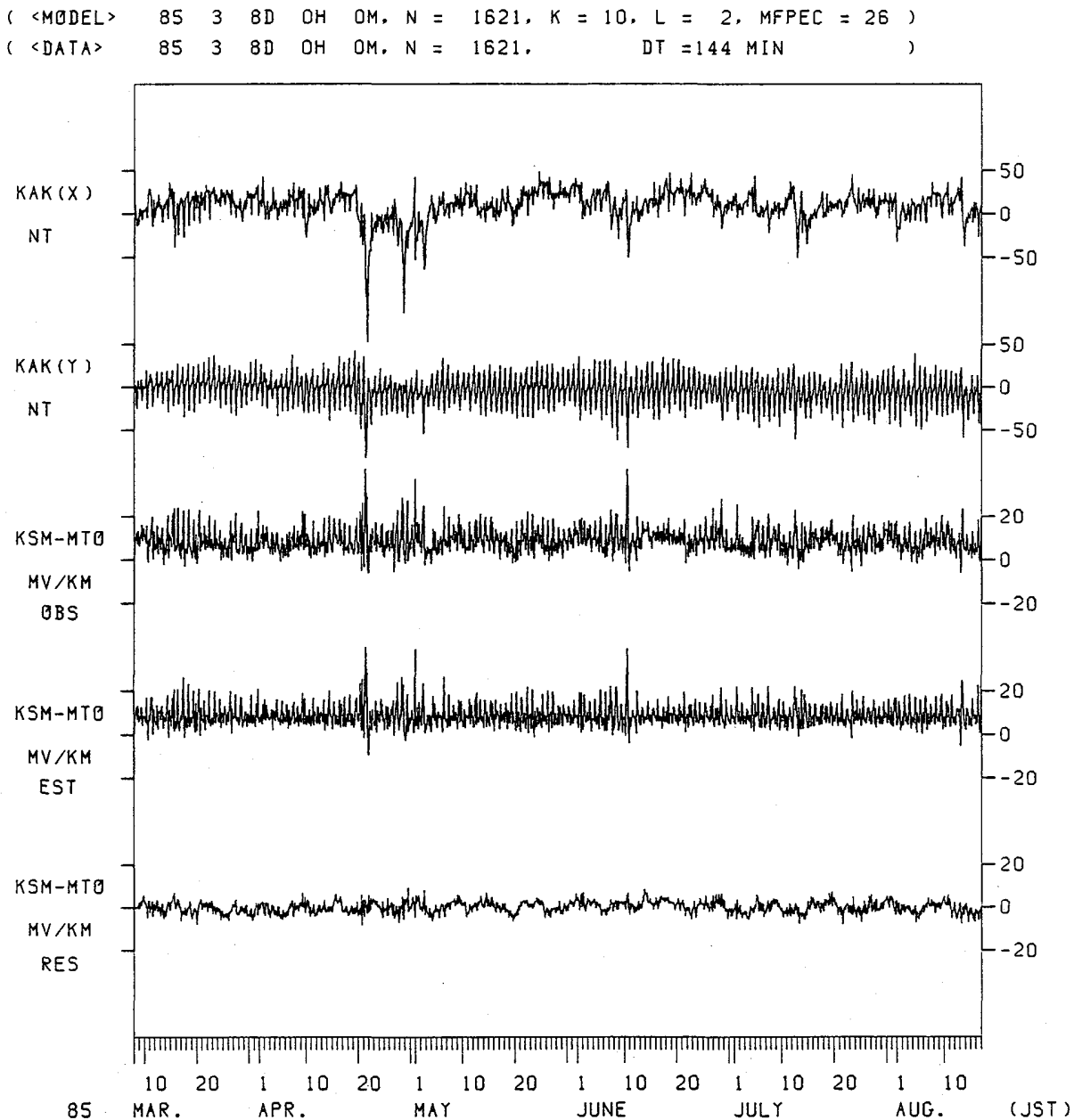

Fig.15 Result obtained by applying a model to the interval from March 8 to August 16, 1985. The legends are the same as in Fig.5. (Sampling period is 144 minutes in Fig.15 to 17 .) 

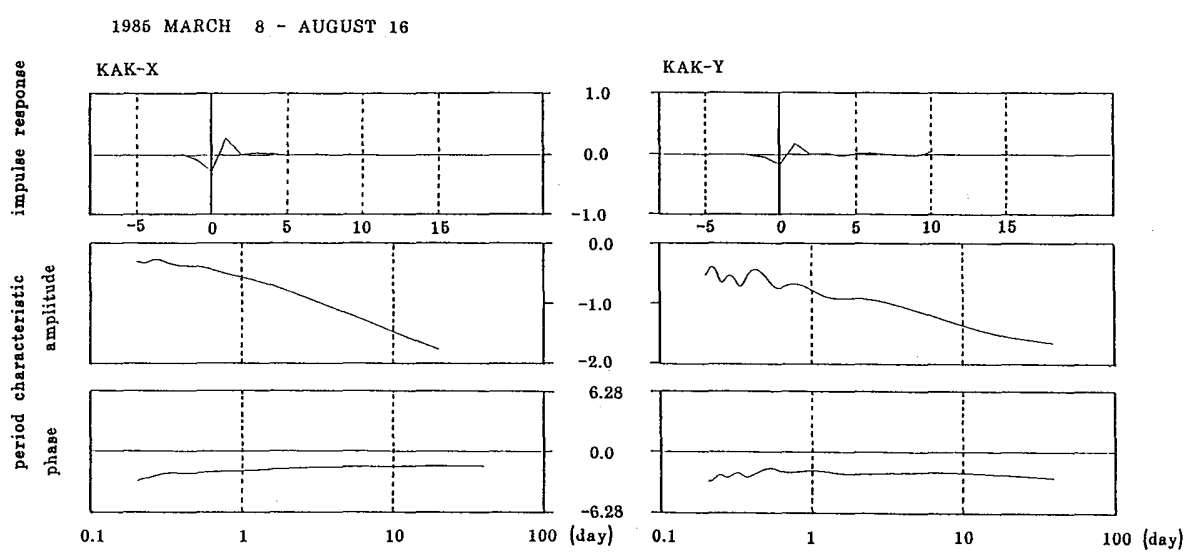

Fig.16 Characteristics of the model with parameters determined due to interval from March 8 to August 16, 1985. The legends are the same as in Fig.4.
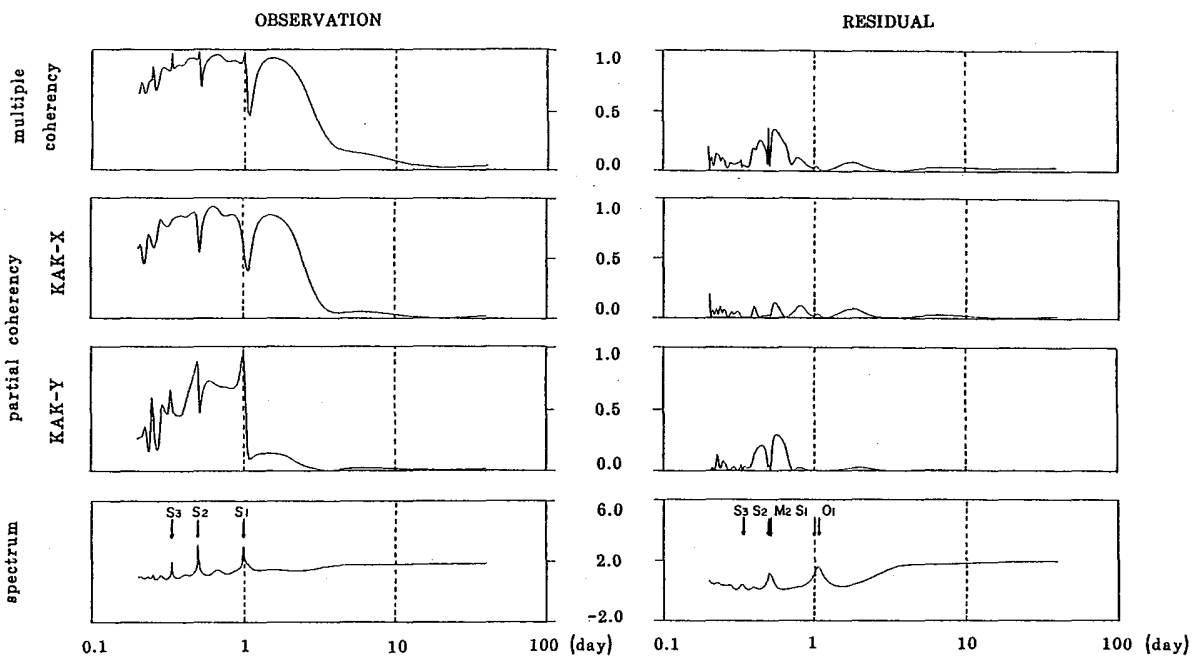

Fig.17 Characteristics in the frequency domain of the time series in Fig.15. The legends are the same as in Fig.6.

次に，サンプリング間隔60分の場合の残差に見 られた 5 ～ 7 日程度の周期の変動と地磁気変化と の関連を調べるため, サンプリング間隔144分， データ数1621個（3月 8 日から8月16日までの約 162日間) の笠間一水戸間の観測値にモデルを適 用した。その結果をFig.15に示す。この場合も数 日程度の周期の変動が見られる。Fig.16に係数と その周期特性を示す。係数は土 1 の範囲だけが大 きく，振幅特性もX成分については 1 日より短い 周期に掠いて，Y成分については全周期に招いて 1/ $\sqrt{\mathrm{T}}$ に比例する傾向が見られる。Fig.15の時 系列の周波数領域での性質をFig.17に示す。観測 值に招いて，5〜7日付近の周期でのコヒーレン
シーはかなり低く地磁気変化との関連はあまり大 きくないと考光られる。残差についてはY成分と の間に10〜15時間の周期にやや関連がみられる が，他は应とんどない。観測值のスペクトルでは $\mathrm{S}_{1}, \mathrm{~S}_{2}, \mathrm{~S}_{3}$ の鋭いピークが見られる。一方, 残 差のスペクトルでは $\mathrm{S}_{1}$ のピークがなくなり $\mathrm{O}_{1}$

(約 $25.82 \mathrm{~h}$ ) のピークが見られ， $\mathrm{S}_{2}$ のピークが かなり低くなり $\mathrm{M}_{2}$ (約12.42 h) のピークも見ら れ， $\mathrm{S}_{3}$ のピークも非常に低くなっている。残差 の時系列に見られる数日周期の変動については地 磁気変化との関連はみられない。また，サンプリ ング間隔が60分の場合の結果 (Fig.12) と比較し て, 数時間以下の短周期の変化を除いて良く一致 
している。

\section{4.まとめ}

N T Tの電話局のアースとその間の通信ケーブ ル施設を利用して観測している地電位差の観測值 から, 地磁気変化の水平成分の観測值を使って, 地磁気変化による誘導電位変化の部分を除去する ことを試みた。まず，地電位差と地磁気変化の水 平成分との間に時間領域でのモデルを仮定し，そ れを適当な区間のデータにあてはめそのパラメー タを決定した。さらにそれに基づいて地磁気変化 による誘導電位変化を推定し, 地電位差の観湘值 から差し引いた残差を計算した。その結果，数時 間から 3 日ぐらいの周期の変化についてはかなり 除去することができた。また残差のスペクトルに $\mathrm{O}_{1}$ や $\mathrm{M}_{2}$ の周期のピークが見られだ。

地電位差変化の地磁気変化に対する比は 1 日よ り短い周期で $1 / \sqrt{\mathrm{T}}$ に比例する傾向があるが， 地電位差変化が北西－南東の卓越方向をもら，ほ ぼ東西の基線である笠間一水戸間の地電位差観測 值に地磁気変化の南北成分（X）だけでなく東西 成分 $(Y)$ にる誘導と考えられる変化が見られ る。これはmagneto-telluric法の観測で多くの場 合電場と磁場の振幅比は $1 / \sqrt{\mathrm{T}}$ に比例するが位 相差が $\pi / 4$ とならず，媒質を一様とすることが 困難である（力武，1972）ことと同様に，この付 近の電磁気的地下構造が，不均質性，異方性の一 方あるいは両方をすつことを示唆している。

仮定したモデルに関して次のような問題点があ げられる。(1)モデルのパラメータが，あてはめる 区間によって異なる。(2)区間Bについて求めたパ ラメータをもつモデルを用いて得た残差の短周期 変化の振幅がモデル区間とそれ以外の区間で変化 する。(3)区間 Aについて求めたパラメータをもつ モデルを用いて他の区間Bの残差を計算すると地 磁気変化との関連がみられた。

これらの問題点の理由として次のことが考えら れる。(1)仮定したモデルが地磁気変化のらち水平 2 成分だけを使っている。(2)モデルをあてはめた 区間が現象の一般的性質から偏った性質をもって いる。したがって, 地磁気変化のZ成分も考慮す
るなどのモデルの改良が必要であり，またできる だけ広い周期帯域の変化をもつ区間を選んでモデ ルをあてはめなければならないと考えられる。

残差に見られる $\mathrm{O}_{1}$ や $\mathrm{M}_{2}$ の周期の変化が地球潮 汐によるものであるか，あるい海洋潮汐の影響 によるものであるか今後検討していさたい。さら に残差の時系列で見られる数日程度の周期をもつ 変動が，人間活動に伴らノイズであるのか，ある いは自然電位変化であるのか興味ある問題である。

地電位差観測は日本電信電話株式会社の御好意 により行われて招り感謝いたします。柿岡磁気観 測所には，地磁気・地電位データを使用させてい ただき感謝いたします。なおスペクトル解析には 統計数理研究所によって発表されている“時系列 の解析と制御のためのプログラムパッケージ” T I MS A C （赤池・中川，1972）を利用した。

\section{参 考文 献}

Mori.T.,1987: Variations in the Geoelectric Field with Relation to Crustal Conditions of the Earth , Geophys. Mag. (in press)

赤池弘次・中川東一郎, 1972 : ダイナミックシステム の統計的解析と制御，サイエンス社，123-187

赤池弘次, 1976 ：情報量基準 A I C とは何か, 数理科 学, №.153,5-11

水戸地方気象台, 1985 : 茨城県気象月報

森俊雄, 1985 : 長基線地電位試験観測, 気象研究所研究 報告, 36,149-155

力武常次, 1972：地球電磁気学, 岩波書店, 393-397

坂元慶行・石黒真木夫・北川源四郎, 1983：情報量統 計学, 共立出版, 42-64

柳原一夫・横内恒雄, 1967 ：地震に伴う地電流の異常, 地磁気観測所技術報告, 7,53-58

吉松隆三郎, 1937a：地電流の地方的並に局所的研究， 気象集誌. $15,145-158$

吉松隆三郎，1937b：昭和11年12月 27 日伊豆新島強震及 び同年10月26日安房野島崎沖顕著地震と地電 流の変化に就いて, 気象集誌, 15,158-160

吉松隆三郎，1938：昭和13年 1 月 12 日紀伊水道強震之 地電位差の異常, 気象集誌, 16,295-297

吉松隆三郎, 1943 : 昭和18年 9 月 10 日鳥取地震と地電 位差の变化, 地磁気観測所要報, 5,66-67

吉松隆三郎, 1984：昭和19年12月 7 日東南海地震と柿 岡の地電位差の異常変化, 地磁気観測所要報, 20,61-64. 


\section{地磁気変化による誘導電位変化の除去の試み}

\section{高山 寛美・森 俊雄}

地磁気変化とそれによる誘導電位変化との間の時間領域におけるモデルを仮定し，観測値にあてはめそのパラ メータを決定した。このモデルによって誘導電位変化を推定し、地電位差観測値からの残差を計算した。

その結果, この方法によって数時間から 3 日ぐらいの周期の誘導電位変化を除去することができた。観測値のス ペクトルが $\mathrm{S}_{1}, \mathrm{~S}_{2}, \mathrm{~S}_{3}$ 等の周期にピークをもつのに対し, 残差のスペクトルはO $\mathrm{I}_{1} \mathrm{M}_{2}$ の周期にピークをもつ。 